\title{
Clinical TNM Finding
}

National Cancer Institute

\section{Source}

National Cancer Institute. Clinical TNM Finding. NCI Thesaurus. Code C48881.

TNM staging performed with access to clinical information only. 